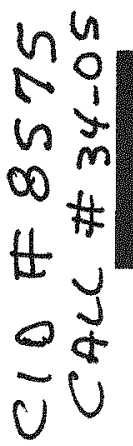

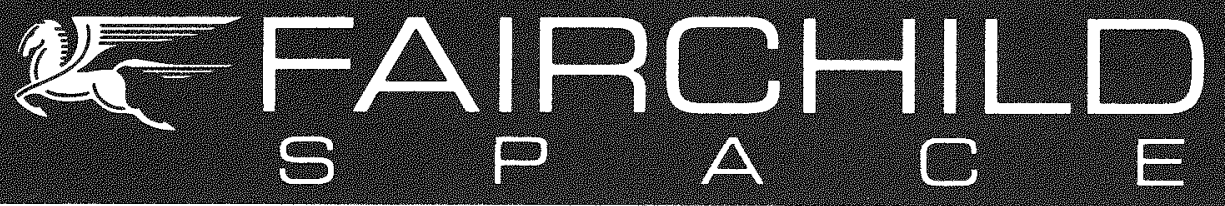

IECEC 94-4128

\title{
EFFECT OF FUEL AND DESIGN OPTIONS ON RTG PERFORMANCE VERSUS PFF POWER DEMAND
}

\author{
Alfred Schock and Chuen Tak Or \\ Fairchild Space and Defense Corporation \\ 20301 Century Blvd. \\ Germantown, MD 20874
}

June 1994 


\section{DISCLAIMER}

This report was prepared as an account of work sponsored by an agency of the United States Government. Neither the United States Government nor any agency Thereof, nor any of their employees, makes any warranty, express or implied, or assumes any legal liability or responsibility for the accuracy, completeness, or usefulness of any information, apparatus, product, or process disclosed, or represents that its use would not infringe privately owned rights. Reference herein to any specific commercial product, process, or service by trade name, trademark, manufacturer, or otherwise does not necessarily constitute or imply its endorsement, recommendation, or favoring by the United States Government or any agency thereof. The views and opinions of authors expressed herein do not necessarily state or reflect those of the United States Government or any agency thereof. 


\section{DISCLAIMER}

Portions of this document may be illegible in electronic image products. Images are produced from the best available original document. 
IECEC 94-4128

\title{
EFFECT OF FUEL AND DESIGN OPTIONS ON RTG PERFORMANCE VERSUS PFF POWER DEMAND
}

\author{
Alfred Schock and Chuen Tak Or \\ Fairchild Space and Defense Corporation \\ 20301 Century Blvd. \\ Germantown, MD 20874
}

June 1994 


\title{
EFFECT OF FUEL AND DESIGN OPTIONS ON RTG PERFORMANCE VERSUS PFF POWER DEMAND
}

\author{
Alfred Schock and Chuen Tak Or \\ Fairchild Space and Defense Corporation \\ Germantown, MD 20874
}

\begin{abstract}
Previous publications by the author described detailed design studies of a number of radioisotope power systems for the Pluto Fast Flyby (PFF) mission. The systems studied employed General Purpose Heat Source (GPHS) modules and a variety of conversion systems (thermoelectric, Stirling, and thermophotovoltaic) for transforming the isotope heat into electricity. The present paper confines its attention to the relatively conservative option employing standard thermoelectric unicouples, since that may be the only one flight-ready for the projected PFF launch in 2001.
\end{abstract}

Instead of the previously studied parametric assumptions of thermal power, the present study examines three specific fuel options: The first option, with the lowest thermal power, is to use the heat source modules from the F5 RTG, which was a spare flight unit for the 1989-launched Galileo mission and also for the upcoming Cassini mission. Its fuel was fabricated in 1982 and will have undergone radioactive decay for at least 18 years at the time of the PFF launch. Nevertheless, there is great interest in the possibility of using these existing heat source modules, because they would enable very substantial cost savings.

The second fuel option is to use newly reprocessed fuel made at the end of the Department of Energy's (DOE's) current production run for NASA's Cassini mission. That production run is scheduled to be completed by the end of 1994 . This option would yield an intermediate thermal power density, and would be the option yielding the lowest gamma emission rate.

The third fuel option would be to use the Pu-238 obtained from Russia under the recently signed purchase agreement. This option could yield the highest thermal power, even higher than the maximum levels analyzed in our parametric studies.
The previous RTG design studies were based on the use of five standard GPHS modules per generator. In response to a request from JPL, the present study derives EOM power predictions for RTGs with five, six, and seven heat source modules, for each of the three fuel options described above, and compares the results with JPL's latest (February 1994) power demand goals, which are $10 \%$ higher than their 1992 baseline goals.

Our results show that even with the highenrichment Russian fuel, an RTG with five heat source modules could only meet the power demand plus $20 \%$ contingency reserve, but not the additional $10 \%$ margin stipulated by JPL. Thus, at least six heat source modules are required to fully meet JPL's EOM power goal.

For an RTG with six heat source modules (which increases the RTG mass by $2.3 \mathrm{~kg}$ ), the use of Russian fuel would provide plenty of margin, the use of new U.S. fuel would still fall somewhat short of meeting JPL's stipulated $10 \%$ margin, and the use of the aged, depleted F5 fuel modules would provide no margin at all. A companion paper presented at this conference explores RTG design modifications for meeting JPL's EOM power goal with the depleted fuel modules, and also for reducing the RTG's mass to compensate for the addition of the sixth heat source module.

\section{BACKGROUND}

The planet Pluto and its large moon Charon orbit the sun with a period of 248 years, at distances of 30 to 50 Astronomical Units. Its remoteness from the Earth has impeded efforts to obtain clear images with even the best telescopes, and is the reason why it is the only planet in the solar system not yet explored by spacecraft. As a result, there is great interest in the scientific community in taking a closer look at Pluto, Charon, and Pluto's atmosphere by means of a spacecraft reconnaissance ${ }^{1}$. 
That interest is made more urgent by the imminent collapse of the planet's atmosphere. Pluto recently passed its perihelion and will not do so again until the year 2237. Because of extreme cold as the planet recedes from the Sun, its atmosphere will undergo condensation in the decade from 2010 to 2020 . Until then we have a unique opportunity to study the atmosphere's chemistry, dynamics, hydrodynamic and solar wind interactions. To take advantage of that opportunity, which won't recur for over 200 years, and of favorable illumination conditions, the Jet Propulsion Laboratory (JPL) has been studying a Pluto Fast Flyby (PFF) mission for NASA ${ }^{2,3}$.

As its name implies, the mission contemplates a spacecraft to "fly by" the planet rather than to orbit or land on it. This simplification permits major size, mass, and cost reductions, and greatly shortens the time for development of the spacecraft and for transit to Pluto, allowing arrival before atmospheric collapse. JPL is considering two spacecraft to be launched in the 2000-2001 time frame and arriving at Pluto after an eight-year direct flight (no gravity assist). The data collected during the brief Pluto flyby (including characterization of its global geology and morphology, its surface composition, and of its atmospheric structure and composition) would be transmitted to Earth during a six-week post-encounter cruise. (This is much shortened from the original data return period, by changing to larger transmission and receiving antennas.)

To support NASA and JPL, the Department of Energy's Radioisotope Power Systems Division commissioned Fairchild Space and Defense Corporation to prepare conceptual designs for a variety of PFF power source options, to help clarify the available options and to provide reliable mass estimates and technology status assessments. The study results were designed to support informed trade-off decisions by program management. The results for three Stirling and five thermoelectric options were presented last year ${ }^{4,5}$ and the results for a thermophotovoltaic option will be presented at this year's IAF Conference ${ }^{6}$.

Although the more advanced power conversion options offer the prospect of substantially higher efficiencies, lower masses, and lower fuel loadings and costs, there is no assurance that those options could be flight-ready in time for the planned PFF launch in 2001. Therefore, JPL decided to baseline the conservative option of a scaled-down derivative of the GPHS/RTG, which was flown on the Galileo and Ulysses missions and is scheduled to be used in the upcoming Cassini mission.
The purpose of the present study, requested by JPL, is to determine the effect of the number of heat source modules and of three specific fuel options on that RTG's power output profile, and to compare that power profile with JPL's power demand schedule.

\section{RADIOISOTOPE HEAT SOURCE}

All the options discussed in this paper are based on the General Purpose Heat Source (GPHS) modules? ${ }^{7}$ These are the same modules that were used in the RTGs flown on the Galileo and Ulysses missions after passing stringent safety reviews based on very extensive safety analyses and tests, and that are slated for launch on the upcoming Cassini mission.

Fig. 1 General-Purpose Heat Source Module (250 Watts) Sectioned at Mid-Plane

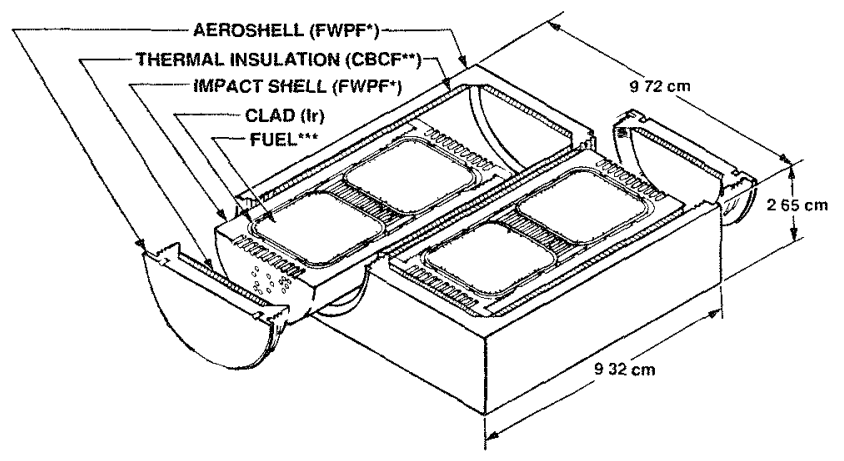

"Fine-Weave Prerced Fabric, a 90\%-dense 30 carbon-carbon composite ** Carbon-Bonded Carbon Fibers, a 10\%-dense high-temperature insulator ***62 5-watt 238 PuO 2 pellet

As shown in Figure 1, each GPHS module has a nominal thermal power of 250 Watts (at the time of fuel separation), and contains four ${ }^{238} \mathrm{PuO}_{2}$ fuel pellets encapsulated in iridium-alloy clads designed to contain or immobilize the fuel in case of accidents before, during, and after launch. The remaining module components are graphitic and are designed to protect the integrity of the iridium clads. There are two impact shells and one aeroshell made of fineweave pierced fabric (FWPF), a very tough hightemperature material. There are two fuel capsules per impact shell and two impact shells per aeroshell. The impact shells help to prevent breach of the clads during impact, and the aeroshell serves as an ablator in case of inadvertent atmospheric reentry. Between the impact shells and the aeroshell is a hightemperature thermal insulator consisting of carbonbonded carbon fibers $(\mathrm{CBCF})$, to prevent overheating of the clads during the reentry heat pulse and overcooling and embrittlement of the clads during the subsequent subsonic atmospheric descent before earth impact. 
The 1993 PFF RTG design assumed a nominal thermal power of 250 watts per module at the beginning of mission. The present study examined three specific fuel options:

- recently imported Russian fuel, yielding a BOM thermal power of $254 \mathrm{~W} /$ module,

- fuel made at the end of DOE's current production run for the Cassini mission, yielding a thermal power of $231 \mathrm{~W} /$ module at the time of PFF launch,

- and fuel from the F5 RTG, which was fabricated in 1982 as a spare for the 1989-launched Galileo mission, and which will yield a thermal power of $220 \mathrm{~W} /$ module at the time of PFF launch.

For each of these fuel options, JPL had requested that we analyze RTGs with 5,6 , and 7 heat source modules.

\section{THERMOELECTRIC UNICOUPLES}

The study was based on unicouple designs that are identical to those used in RTGs flown on the LES 8/9, Voyager, Galileo, and Ulysses missions and are slated for launch on the Cassini mission. These unicouples have demonstrated exceptional reliability and endurance. They have operated in space for up to 17 years, always far beyond their original design goal.

\section{Fig. 2 Unicouple}

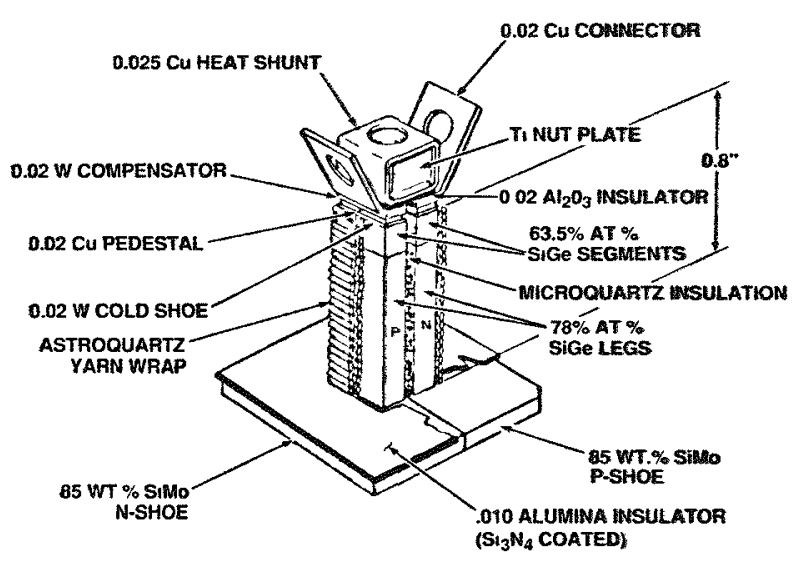

As shown in Figure 2, each unicouple contains an n-doped and a p-doped SiGe leg, which are joined together by a SiMo hot-shoe to form the couple. The hot-shoe also serves as a heat collector to concentrate the heat which the heat source radiates across a vacuum gap. There is no contact between the heat source and the thermoelectric couples. The cold ends of the thermoelectric legs are bonded to electrical and thermal conductors and to mechanical mounting hardware. The gap between the two legs is filled with quartz fibers, and their periphery is wrapped with quartz yarn.

\section{RTG OPTIONS}

Figure 3 shows cross-sectional views of an RTG with 5 heat source modules and 10 rings of 16 unicouples. This is consistent with previously flown RTGs in which there were 2 unicouple rings per heat source module. As shown, the unicouples are embedded in multifoil thermal insulation, and are mounted on the inside of the finned RTG housing. There is no contact between the spring-loaded heat source stack and the cantilevered unicouples. All heat transfer is by radiation to the unicouples' hot shoes. Series-parallel connections between unicouples are in the space between the thermal insulation and the housing. The generated power emerges through a vacuum feedthrough. The 5module RTG has a mass of $15.8 \mathrm{~kg}$.

\section{Fig. 3 Cross-Sectional View of RTG with 5 Heat Source Modules}

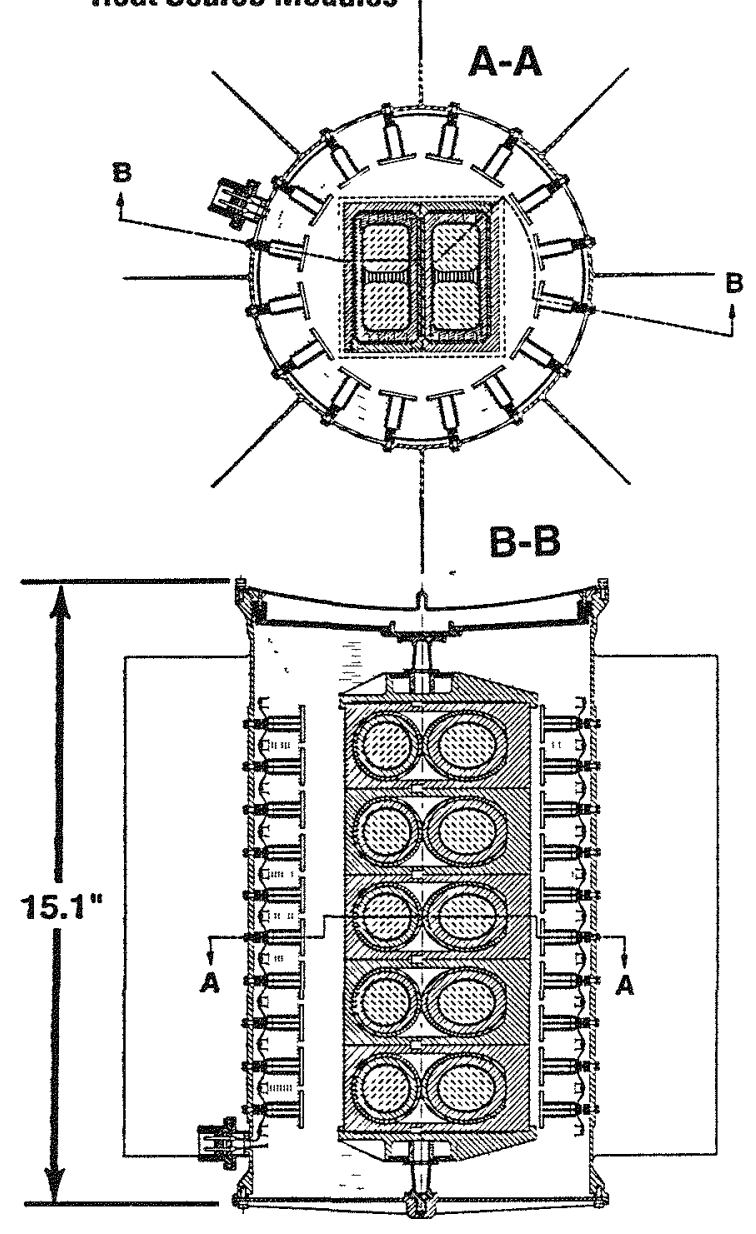


Similar designs of RTGs with 6 and 7 heat source modules and respectively with 12 and 14 unicouple rings are depicted in Figure 4. These had respective heights of 17.2 and 19.3 inches, and respective masses of $\mathbf{1 8 . 1}$ and $20.4 \mathrm{~kg}$.

Each of these designs was analyzed for the three previously mentioned fuel options. (Note: For the Galileo Spare option, only RTGs with 5 and 6 heat source modules were analyzed. The F5 spare unit contains 18 heat source modules, which only allows a maximum of 6 modules for the PFF mission's two flight units and one spare RTG.)

Each of the eight designs was subjected to a detailed, coupled thermal and electrical analysis. The analyses employed previously published methodologies to compute the RTG's BOM performance 8 and EOM performance?. The salient results of those analyses are summarized in Table 1.

Fuller results are displayed in Figure 5, which shows the output power history of each option from beginning to end of mission.

\section{COMPARISON WITH PFF POWER DEMAND}

The next step is to compare the predicted power profiles for the various cases with JPL's stipulated power demand schedule. The latest available version $(2 / 18 / 94)$ of that schedule is summarized in Table 2. As seen, the mission consists of an 8-year preencounter phase with a weekly 4-hour downlink period and several 30-minute prepropulsive and propulsive maneuvers, a 30-day encounter phase with daily 16 hours of data gathering and 8 hours of data transmission, followed by a 6-week post-encounter cruise with full-time data transmission. For each activity, the table lists the breakdown of the power demand and the total demand with a $20 \%$
Fig.4 Cross-Sectional View of RTGs with 6 and 7 Heat Source Modules

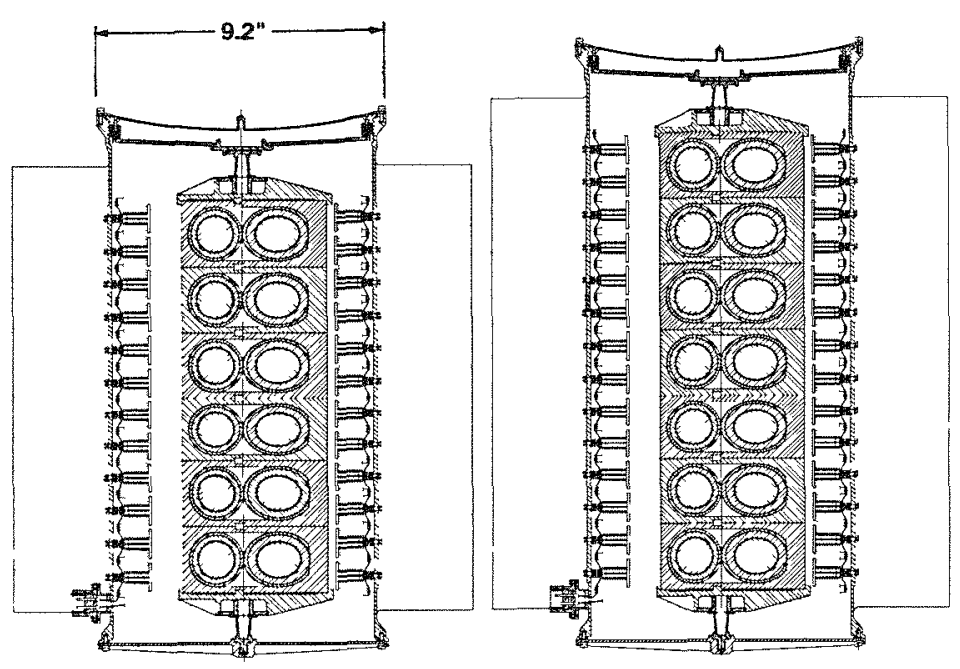

Table 1 Effect of Fuel Option and Number of Heat Source Modules on Performance of RTGs

\begin{tabular}{|c|c|c|c|c|c|c|c|c|}
\hline Fuel Option & \multicolumn{3}{|c|}{ Russlan } & \multicolumn{3}{|c|}{ U.S. (Cassini) } & \multicolumn{2}{|c|}{ GLL Spare (F5) } \\
\hline Pu-238 Enrichment, \% & \multicolumn{3}{|c|}{87.7} & \multicolumn{3}{|c|}{797} & \multicolumn{2}{|r|}{826} \\
\hline $\begin{array}{l}\text { Thermal Watts per Module } \\
\text { BOM (Jan 2000) } \\
\text { EOM (Mar 2008) }\end{array}$ & \multicolumn{3}{|c|}{$\begin{array}{l}254 \\
238\end{array}$} & \multicolumn{3}{|c|}{$\begin{array}{l}231 \\
216\end{array}$} & \multicolumn{2}{|r|}{$\begin{array}{l}220 \\
206\end{array}$} \\
\hline $\begin{array}{l}\text { Heat Source Modules } \\
\text { RTG Mass, kg } \\
\text { Optimum RTG Voltage }\end{array}$ & $\begin{array}{c}5 \\
15.8 \\
19\end{array}$ & $\begin{array}{c}6 \\
18.1 \\
23\end{array}$ & $\begin{array}{c}7 \\
20,4 \\
27\end{array}$ & $\begin{array}{c}5 \\
15.8 \\
17\end{array}$ & $\begin{array}{c}6 \\
18.1 \\
21\end{array}$ & $\begin{array}{l}7 \\
20.4 \\
25\end{array}$ & $\begin{array}{c}5 \\
15.8 \\
16\end{array}$ & $\begin{array}{c}6 \\
18,1 \\
20\end{array}$ \\
\hline $\begin{array}{l}\text { Hot-Junction Temp., }{ }^{\circ} \mathrm{C} \\
\text { BOM } \\
\text { EOM }\end{array}$ & $\begin{array}{l}992 \\
948\end{array}$ & $\begin{array}{c}1003 \\
959\end{array}$ & $\begin{array}{c}1012 \\
970\end{array}$ & $\begin{array}{l}916 \\
875\end{array}$ & $\begin{array}{l}930 \\
889\end{array}$ & $\begin{array}{l}940 \\
899\end{array}$ & $\begin{array}{l}878 \\
839\end{array}$ & $\begin{array}{l}893 \\
854\end{array}$ \\
\hline $\begin{array}{l}\text { Cold-Junction Temp., }{ }^{\circ} \mathrm{C} \\
\text { BOM } \\
\text { EOM }\end{array}$ & $\begin{array}{l}254 \\
245\end{array}$ & $\begin{array}{l}262 \\
253\end{array}$ & $\begin{array}{l}234 \\
228\end{array}$ & $\begin{array}{l}240 \\
231\end{array}$ & $\begin{array}{l}247 \\
238\end{array}$ & $\begin{array}{l}253 \\
244\end{array}$ & $\begin{array}{l}233 \\
224\end{array}$ & $\begin{array}{l}240 \\
231\end{array}$ \\
\hline $\begin{array}{l}\text { Efficlency, } \% \\
\text { BOM } \\
\text { EOM }\end{array}$ & $\begin{array}{l}7.1 \\
6.1\end{array}$ & $\begin{array}{l}72 \\
6.2\end{array}$ & $\begin{array}{l}7.3 \\
6.1\end{array}$ & $\begin{array}{l}65 \\
5.9\end{array}$ & $\begin{array}{l}66 \\
5.9\end{array}$ & $\begin{array}{l}67 \\
6.0\end{array}$ & $\begin{array}{l}62 \\
5.7\end{array}$ & $\begin{array}{l}63 \\
57\end{array}$ \\
\hline $\begin{array}{l}\text { Power Output, Watts(e) } \\
\text { BOM } \\
\text { EOM }\end{array}$ & $\begin{array}{l}90 \\
73\end{array}$ & $\begin{array}{l}109 \\
88\end{array}$ & $\begin{array}{l}129 \\
102\end{array}$ & $\begin{array}{l}75 \\
64\end{array}$ & $\begin{array}{l}91 \\
77\end{array}$ & $\begin{array}{c}108 \\
90\end{array}$ & $\begin{array}{l}68 \\
59\end{array}$ & $\begin{array}{l}83 \\
71\end{array}$ \\
\hline
\end{tabular}

Fig. 5 Effect of Fuel Option and Number of Heat Source Modules on Power Profile and Mass of RTG for Pluto Mission

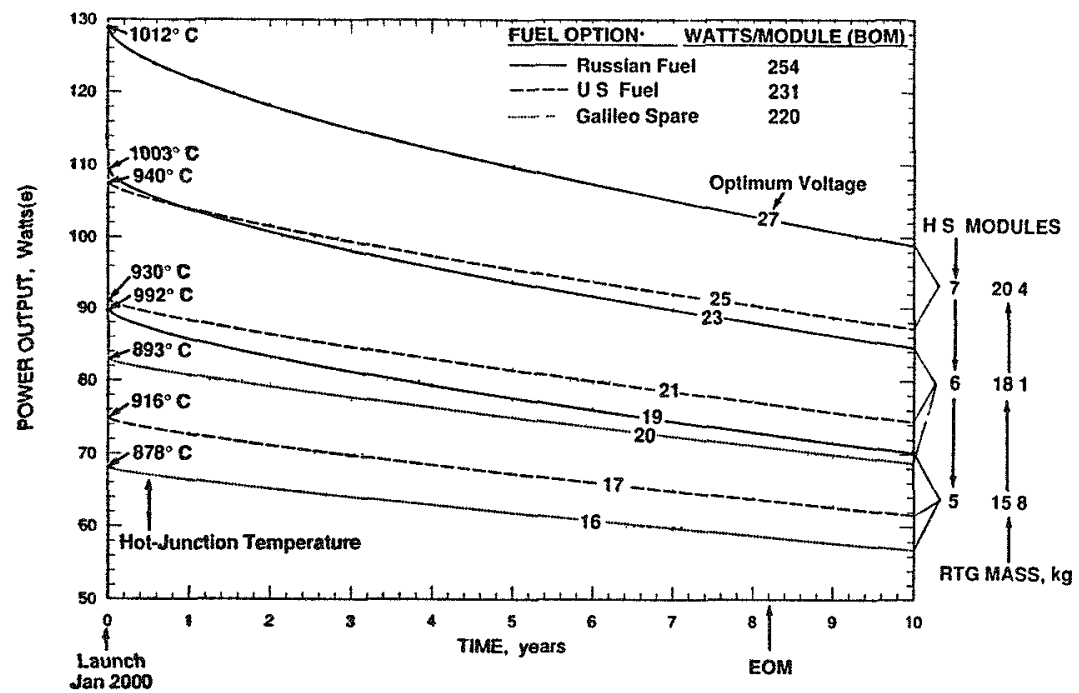


contingency allowance plus a $10 \%$ margin, which is JPL's stipulated power goal. As will be seen, the most critical demands are the last of the prepropulsive maneuvers and the last of the weekly downlinks before encounter, and the data transmissions after encounter.

For the three fuel options, Figure 6 compares these critical power demands with the predicted power profiles for RTGs with 5 and 6 heat source modules. As shown, for an RTG with 5 heat source modules none of the fuel options meets JPL's $10 \%$ margin goal, while an RTG with six heat source modules more than meets the JPL goal with Russian fuel, almost meets it with U.S. (Cassini) fuel, but still falls considerably short of meeting JPL's 10\% margin goal with the depleted fuel from the aged Galileo spare (F5) RTG.

This last conclusion is disappointing, because NASA would much prefer to use the F5 heat source modules, which have already been built and paid for. Therefore, Fairchild proceeded to investigate a number of design modifications of the RTG with six depleted heat source modules. As shown in the companion paper presented next ${ }^{10}$, a relatively simple design modification makes it possible to meet JPL's stipulated $10 \%$ power margin; a second design modification makes it possible to recover all of the mass and size increase incurred in going from five to six heat source modules; and a third modification (in operating mode) could increase the EOM power margin to $16 \%$.
Table 2. JPL's 1994 Baseline Power Demand Schedule for PFF (2-18-94)

\begin{tabular}{|c|c|c|c|c|c|c|}
\hline \multirow{2}{*}{$\begin{array}{l}\text { Mission Phase } \\
\text { Duretion } \\
\text { Mode } \\
\text { Aclivity Time }\end{array}$} & \multicolumn{3}{|c|}{$\begin{array}{l}\text { Pre-Encounter } \\
8 \text { years }\end{array}$} & \multicolumn{2}{|c|}{$\begin{array}{c}\text { Encounter } \\
\mathbf{3 0} \text { days } \\
\end{array}$} & \multirow{2}{*}{$\begin{array}{c}\begin{array}{c}\text { Post- } \\
\text { Encounter } \\
6 \text { weeks }\end{array} \\
7 \\
24 \text { hr/day }\end{array}$} \\
\hline & $\begin{array}{c}1 \\
164 \mathrm{hr} / \mathrm{wk}\end{array}$ & $\begin{array}{c}2 \\
4 \mathrm{hr} / \mathrm{wk}\end{array}$ & $\begin{array}{c}3 \\
20 \times 30 \mathrm{mln}\end{array}$ & $\begin{array}{c}6 \\
16 \text { hriday }\end{array}$ & $\begin{array}{c}6^{*} \\
8 \mathrm{ht} / \mathrm{day}\end{array}$ & \\
\hline Activity & Cruise & Downlink & $\begin{array}{l}\text { Pre- } \\
\text { Propulsive } \\
\text { Maneuvers }\end{array}$ & $\begin{array}{c}\text { Dala } \\
\text { Gathering }\end{array}$ & \multicolumn{2}{|c|}{$\begin{array}{c}\text { Dala } \\
\text { Transmission }\end{array}$} \\
\hline $\begin{array}{l}\text { Power (Watts) } \\
\text { Telecommunication } \\
\text { Power Conditioning } \\
\text { Altlude Control } \\
\text { Data Processing } \\
\text { Propulsion } \\
\text { Thermal Control } \\
\text { Sclence }\end{array}$ & $\begin{array}{l}9.0 \\
12.2 \\
9.7 \\
136 \\
04 \\
10 \\
1.0\end{array}$ & $\begin{array}{l}24.0 \\
14.7 \\
9.7 \\
8.6 \\
16.9 \\
10 \\
1.0\end{array}$ & $\begin{array}{c}9.0 \\
15.1 \\
9.9 \\
8.6 \\
16.9 \\
1.0 \\
1.0\end{array}$ & $\begin{array}{l}8.0 \\
135 \\
16.0 \\
66 \\
04 \\
10 \\
60\end{array}$ & \multicolumn{2}{|c|}{$\begin{array}{l}240 \\
14.4 \\
9.7 \\
136 \\
0.4 \\
10 \\
00\end{array}$} \\
\hline $\begin{array}{l}\text { Tolal Power Dernand } \\
\text { Incl. } 20 \% \text { contingency } \\
\text { Incl. } 10 \% \text { margin }\end{array}$ & $\begin{array}{l}468 \\
562 \\
61.8\end{array}$ & $\begin{array}{l}59.3 \\
71.2 \\
63\end{array}$ & $\begin{array}{l}614 \\
737 \\
81.1\end{array}$ & $\begin{array}{l}534 \\
641 \\
70.5\end{array}$ & \multicolumn{2}{|c|}{$\begin{array}{l}581 \\
697 \\
76.7\end{array}$} \\
\hline Energy Demand, kW hr & 4216 & 130 & 1 & 34 & \multicolumn{2}{|c|}{96} \\
\hline
\end{tabular}

Fig. 6 Effect of Fuel Option on Power Output Versus Demand
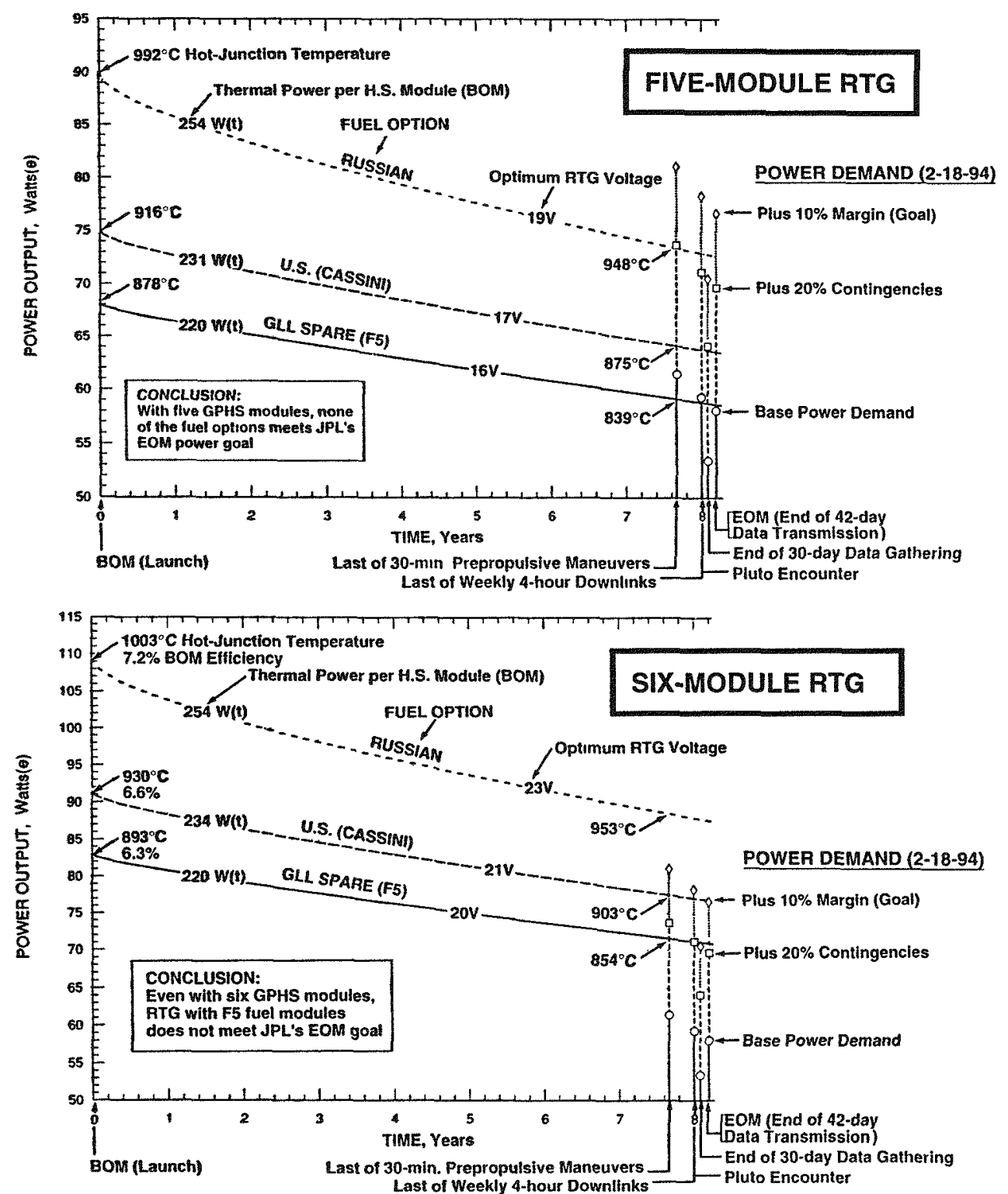


\section{REFERENCES}

1 Stern, Allen, "The Pluto Reconnaissance Flyby Mission," in Trans. of the American Geophysical Union, Vol. 74\#7, pp 73, 76-78.

2 Staehle, R.L., et. al., "Pluto Mission Progress Report: Lower Mass and Flight Time through Advanced Technology Insertion," IAF-93Q.5.410, 44th Congress of the International Astronautical Federation, Graz Austria, 16-22 October 1993.

3 Stachle, R.L., et. al., "Pluto Mission Development Status," presented at IAA International Conference on Low-Cost Planetary Missions, Latirel, MD, 12-15 April 1994.

4 Schock, A., "RSG Options for Plito Fast Flyby Mission," IAF-93-R.1.425b, 44th Congress of the International Astronautical Federation, Graz, Austria, 16-22 October 1993.

5 Schock, A., "RTG Options for Pluto Fast Flyby Mission," IAF-93-R.1.425a, 44th Congress of the International Astronautical Federation, Graz, Austria, 16-22 October 1993.

6 Schock, A., et. al. "Radioisotope Thermophotovoltaic System Design and its Application to an Illustrative Space Mission," for presentation at the 45th Congress of the International Astronautical Federation, Jerusalem, 9-14 October 1994.

7 Schock, A., "Design Evolution and Verification of the General-Purpose Heat Source," \#809203 in Proc. of 15th Intersociety Energy Conversion Engineering Conference, held in Seattle, WA, 18-22 August 1980.

8 Schock, A., "Thermal and Electrical Analysis of Mars Rover RTGs," Proc. of the 24th Intersociety Energy Conversion Engineering Conference, held in Washington, D.C., 6-11 August 1989.

9 Schock, A., "Closed-Form Solution for the Effect of Fuel Decay and Thermoelectric Degradation on Output of SiGe RTGs," Proc. of the 26th Intersociety Energy Conversion Engineering Conference, held in Boston, MA, 4-9 August 1991.
10 Schock, A.,Chuen Tak Or, and Vasnath Kumar, "Design Modifications for Increasing the BOM and EOM Power Output and Reducing the Size and Mass of RTG for the Pluto Mission," for presentation at the 29th Intersociety Energy Conversion Engineering Conference, held in Montery, CA, 7-12 August 1994. 